\title{
MODEL PENGEMBANGAN KEMAMPUAN PRA-MEMBACA-MENULIS BERBASIS KARAKTER
}

\author{
Barokah Widuroyekti (barokahw@ut.ac.id) \\ Sulistiyono \\ Program Studi PGSD, FKIP Universitas Terbuka, \\ Kampus C Unair Mulyorejo Surabaya 60115
}

\begin{abstract}
ABSTRAK
Artikel ini disusun berdasarkan penelitian yang bertujuan mengembangkan model pengembangan kemampuan pra-membaca-menulis berbasis pendidikan karakter di TK. Penelitian dilakukan menggunakan pendekatan penelitian pengembangan melibatkan guruguru dan anak-anak di tiga TK Kabupaten Jombang. Prosedur penelitian terdiri atas dua tahap, yakni studi pendahuluan dan pengembangan model. Data dikumpulkan dengan teknik observasi, wawancara, dokumentasi, kuesioner dan uji validasi pakar, serta hasilnya dianalisis dengan teknik analisis kualitatif. Hasil penelitian menunjukkan bahwa guru membutuhkan panduan dan model pengembangan kemampuan pra-membaca-menulis berbasis karakter, serta skenario kegiatan pengembangan. Model pengembangan yang dihasilkan memungkinkan anak mengenal tulisan dan mengembangkan kemampuan pramembaca-menulis melalui cerita. Model pengembangan memuat nilai karakter pada komponen perencanaan, meliputi: tujuan, materi, dan kegiatan, serta pada pelaksanaan meliputi: pendahuluan, inti, dan penutup.
\end{abstract}

Kata kunci: anak usia dini, kemampuan pra-membaca-menulis, pendidikan karakter

\begin{abstract}
The article draws on research that aims to develop a model of the development of prereading-writing ability of a character-based education in kindergarten. The study was used the Research and Development method involving teachers and children at three kindergartens in Jombang. The procedure consists of two phases study, the preliminary studies and model development. Data collected by observation, interviews, documentation, questioner techniques, validation testing experts, and the results are analyzed with qualitative analysis techniques. The results showed that teachers require manual and development model's to pre-reading-writing ability of a character-based, as well as scenario development activity. The model of development gives the possibility for children to develop the ability to recognize text and pre-reading-writing through story. Development model cantains character values on planning, include: objectives, materials, and activities, as well as the implementation, include: introduction, core, and closing activities.
\end{abstract}

Keywords: early childhood, character education, pre-reading-writing abilities

Masalah krusial yang mendasari perlunya pengembangan model dalam upaya mengembangkan kemampuan pra-membaca-menulis pada anak TK mencakup tiga hal pokok. Pertama, membaca menulis merupakan suatu keterampilan yang memiliki peran penting dalam 
kehidupan. Kemampuan baca-tulis sangat dibutuhkan pada era informasi, suatu era disaat informasi tersedia di berbagai media, baik media cetak maupun elektronik. Berbagai informasi tersebut perlu diserap secara cepat dan tepat agar manusia tidak tertinggal oleh perkembangan ilmu pengetahuan dan teknologi, sebagai bagian yang tak terpisahkan dari kehidupan modern saat ini. Dalam konteks inilah, pendidikan memiliki peran penting dalam menyiapkan keterampilan membaca menulis. Keterampilan membaca menulis perlu dikenalkan sejak usia dini. Dalam masa tumbuh kembangnya, anak menyerap semua informasi di sekeliling mereka.

Kedua, mengacu pada Pasal 3 UU No. 20 Tahun2003, bahwa "Pendidikan nasional berfungsi mengembangkan kemampuan dan membentuk watak serta peradaban bangsa yang bermartabat..." maka pendidikan karakter juga merupakan bagian dari kurikulum pendidikan di TK sebagai salah satu peletak dasar pembentukan karakter anak. Pendidikan karakter bangsa dimaknai sebagai pendidikan yang mengembangkan nilai-nilai budaya dan karakter bangsa pada diri peserta didik sehingga nilai-nilai tersebut tertanam pada diri mereka sebagai karakternya sendiri. menerapkan nilai-nilai tersebut dalam kehidupan sebagai anggota masyarakat, dan warga negara yang religius, nasionalis, produktif, dan kreatif (Puskur, 2010). Berbagai hasil penelitian menyebutkan bahwa usia dini merupakan saat yang baik untuk menanamkan dasar pembentukan karakter seseorang. Hasil penelitian menunjukkan bahwa anak-anak usia 2 (dua) tahun sudah dapat diajarkan nilai-nilai moral, bahkan mereka sudah dapat mempunyai perasaan simpati terhadap kesulitan atau penderitaan orang lain (Megawangi, 2009). Hasil studi yang lain menunjukkan bahwa pengalaman anak-anak di masa TK dapat memberikan pengaruh positif terhadap perkembangan anak selanjutnya (Schweinhart dalam Megawangi, 2009).

Ketiga, secara konseptual, pengembangan di TK mengacu kepada struktur program PAUD, mencakup bidang pengembangan pembentukan perilaku dan bidang pengembangan kemampuan dasar melalui kegiatan bermain dan pembiasaan. Lingkup pengembangan meliputi pengembangan nilai-nilai agama dan moral, fisik, kognitif, bahasa, dan sosial-emosional dikembangkan melalui kegiatan pengembangan secara terpadu dengan aspek yang lain, menggunakan pendekatan tematik. Dengan mendasarkan pada konsepsi tersebut, ide pengembangan keterampilan pramembaca-menulis yang dilakukan dengan memadukan pengembangan bahasa dan nilai-nilai moral dalam suatu kegiatan yang terpadu merupakan hal yang perlu segera dilakukan.

Dalam konteks pengajaran bahasa dikenal pendekatan seluruh bahasa (whole language), membaca diajarkan dengan menjaga keutuhan bahasa, artinya bahasa tidak diajarkan secara bagian demi bagian melainkan keseluruhan yang utuh. Pembelajaran bahasa (membaca menulis) menurut konsepsi whole language merupakan bentuk pembelajaran bahasa yang berfokus pada anak, berorientasi pada karya sastra sebagai landas tumpu pembelajaran, dan sedapat mungkin membawa anak dalam situasi komunikasi secara konkret (Frose, 1991).

Pembentukan karakter anak melalui media cerita merupakan bentuk implementasi pendekatan whole language. Cerita anak, baik berupa dongeng maupun cerita yang dikembangkan sendiri oleh guru, digunakan sebagai sarana berlangsungnya peristiwa berbahasa yang memuat nilai-nilai untuk pembentukan karakter. Teks cerita pada umumya disusun dengan muatan pesanpesan moral dan menampilkan kisah serta sisi kemanusiaan dari tokoh cerita. Dengan demikian, penggunaan cerita sebagai materi dalam kegiatan di TK memungkinkan pengembangan kemampuan bahasa dan pendidikan nilai, artinya, selain mengembangkan aspek bahasa juga mempunyai misi memuncakkan domain afektif, yang menurut Driyarkara (dalam Elmubarok, 2009) adalah upaya dalam rangka memanusiakan manusia. Hal ini selaras dengan arah Kebijakan Nasional Pembangunan Karakter Bangsa (Republik Indonesia, 2010) bahwa pembangunan karakter bangsa 
menjadi prioritas utama pembangunan nasional. Tujuan pendidikan karakter adalah (1) mengembangkan potensi kalbu/nurani/afektif peserta didik sebagai manusia dan warga negara yang memiliki nilai budaya dan karakter bangsa, (2) mengembangkan kebiasaan dan perilaku peserta didik yang terpuji dan sejalan dengan nilai-nilai universal dan tradisi budaya bangsa yang religius, (3) menanamkan jiwa kepemimpinan dan tanggung jawab peserta didik sebagai generasi penerus bangsa, (4) mengembangkan kemampuan peserta didik menjadi manusia yang mandiri, kreatif, berwawasan kebangsaan, (5) mengembangkan lingkungan kehidupan sekolah sebagai lingkungan belajar yang aman, jujur, penuh kreativitas dan persahabatan, serta dengan rasa kebangsaan yang tinggi (Wahyuni \& Ibrahim, 2012: 4).

Kegiatan pengenalan membaca menulis dilakukan dengan menyediakan pengalaman membaca dan mengenal kata-kata tertulis. Agar keterampilan berbahasa lisan dan baca tulis dapat ditanamkan pada diri anak, pengalaman penting harus dimiliki anak, yaitu berbicara dan mendengarkan orang lain, serta membaca dengan orang lain (Seefeldt \& Wasik, 2008). Penanaman nilai-nilai karakter dapat dilakukan melalui konteks yang dekat dengan dunia anak. Kegiatan pengembangan dimulai dengan membacakan cerita yang utuh bermuatan nilai-nilai karakter yang baik, kemudian dipadukan dengan pengembangan keterampilan pra-membaca menulis melalui serangkaian pengalaman berhubungan dengan membaca menulis. Dalam kegiatan tersebut juga dikembangkan aspek perkembangan lainnya, seperti perkembangan fisik motorik, seni, kognitif, dan sosial-emosional secara terpadu, sesuai dengan standar isi pada Pendidikan Anak Usia Dini (PAUD).

Sesuai dengan kurikulum pendidikan TK, membaca menulis di TK belum diajarkan secara formal. Artinya, pengembangan membaca menulis di TK bukan mengajarkan membaca menulis formal sebagaimana dilakukan di sekolah dasar melainkan merupakan tahap persiapan membaca menulis. Oleh karena itu, pengembangan terkait dengan baca-tulis disebut dengan pra-membacamenulis. Sesuai dengan tahap perkembangan kognitif yang dikemukakan oleh Piaget (Hurlock, 1992), anak usia dini (2-6 tahun), berada pada tahap praoperasional. Pada tahap praoperasional, anak mampu menggunakan bahasa dan pemikiran simbolik. Artinya, pada tahap ini, anak sudah mampu menggunakan bahasa dan simbol-simbol yang melambangkannya. Pengembangan membaca menulis di TK lebih diarahkan pada kegiatan menstimulasi perkembangan membaca menulis sesuai dengan tahap perkembangan anak. Sesuai dengan tahap perkembangan anak, kegiatan pengembangan di TK harus sesuai dengan prinsip-prinsip pembelajaran di antaranya prinsip berpusat pada peserta didik, beragam dan terpadu, belajar melalui bermain, (Kemdiknas, 2010).

Penelitian terkait dengan pengembangan pra-membaca menulis pernah dilakukan oleh Afandi (http://www.garuda.dikti.go.id/jurnal/detil/id/48:2818/q). Penelitian tersebut menghasilka buku panduan pengasuhan untuk mengembangkan potensi membaca bagi anak usia prasekolah. Hasil penelitian tersebut menunjukkan bahwa harapan orang tua tentang buku panduan pengasuhan membaca secara umum adalah: (1) dapat membimbing anak mengenal huruf sejak dini, (2) dapat mendorong anak gemar membaca, (3) dapat menjadi anak pintar dan kreatif, (4) memudahkan orang tua dan guru TK dalam mengajarkan membaca pada anak, (5) meningkatkan kreatifitas orang tua dalam mengajarkan membaca pada anak, dan (6) dapat diterbitkan yang kemudian akan dikembangkan dan diumumkan menjadi buku panduan untuk orang tua dan guru TK. Hasil penelitian tersebut merekomendasikan kepada peneliti perlunya mengembangkan buku panduan pengasuhan untuk mengembangkan potensi membaca anak usia prasekolah guna melengkapi kekurangan yang ada. 
Artikel ini menyajikan hasil penelitian berupa produk model pengembangan pra-membacamenulis berbasis pendidikan karakter yang sesuai untuk anak di TK. Membaca menulis di TK mengacu pada lingkup perkembangan bahasa, khususnya untuk kelompok $B$, yakni kelompok anak usia 5-6 tahun. Kegiatan pengembangan pra-membaca-menulis di TK bertolak dari penggunaan cerita anak sebagai upaya penanaman nilai karakter pada anak sejak usia dini.

\section{METODE}

Penelitian dilakukan dengan menggunakan pendekatan penelitian Research and Development $(R \& D)$, yakni penelitian yang ditindaklanjuti dengan pengembangan dan diseminasi (Borg \& Gall, 1983). Penelitian pengembangan akan menghasilkan produk dan menguji keefektifan produk (Sugiyono, 2009: 297). Prosedur penelitian dibagi dalam dua tahap, yakni tahap studi pendahuluan dan tahap pengembangan model. Pada tahap studi pendahuluan dilakukan pengumpulan data untuk memperoleh gambaran tentang kebutuhan guru dan pelaksanaan kegiatan pengembangan kemampuan pra-membaca-menulis di TK. Selanjutnya dilakukan analisis kebutuhan dan hasilnya digunakan sebagai dasar untuk menyusun model pengembangan kemampuan pramembaca-menulis berbasis pendidikan karakter di TK. Pada tahap pengembangan model dilakukan penyusunan draf model pengembangan pra-membaca-menulis berbasis karakter di TK. Hasil pengembangan model tersebut kemudian divalidasi oleh validator (pakar dan praktisi/guru) kemudian direvisi berdasarkan masukan validator. Model pengembangan yang telah direvisi selanjutnya diujicobakan di lapangan, yakni diimplementasikan dalam kegiatan pengembangan di TK.

Prosedur dan tahap-tahap penelitian sebagaimana digambarkan dalam bagan alur penelitian pada Bagan 1.

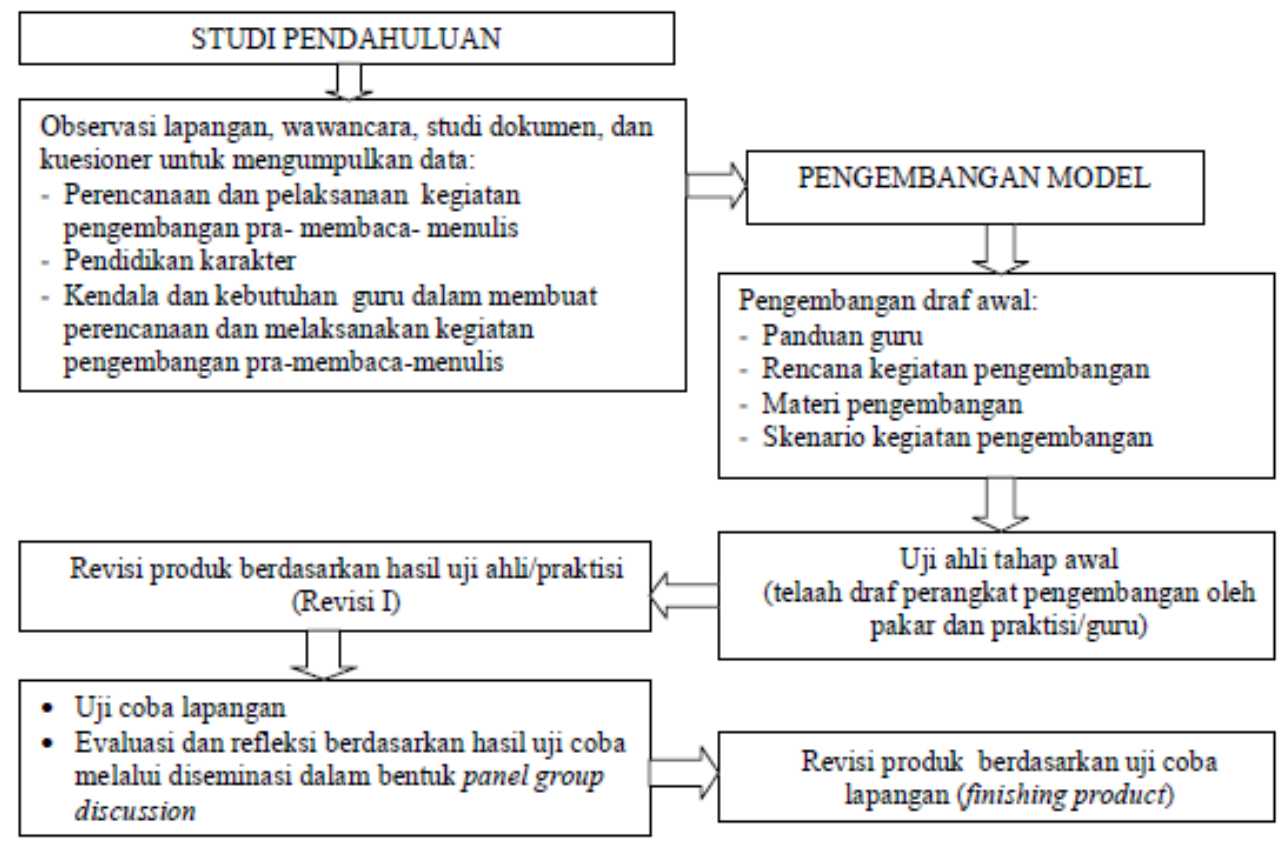

Bagan 1. Alur penelitian

Penelitian dilaksanakan di TK Kabupaten Jombang selama 8 (delapan) bulan mulai dari studi pendahuluan hingga pengembangan model. Studi pendahuluan dilakukan terhadap subyek 
penelitian guru-guru TK untuk memperolah data tentang kebutuhan dalam pngembangan kemampuan pra-membaca-menulis di tiga TK. Penentuan TK sebagai subyek penelitian dilakukan secara random sederhana. Pada tahap pengembangan model, data pengembangan divalidasi oleh tim ahli, yang terdiri atas tenaga ahli bidang studi pendidikan AUD dan tenaga ahli dalam pembelajaran. Lokasi uji coba lapangan ditetapkan 1 TK. Penetapan 1 TK sebagai lokasi uji coba dilakukan dengan teknik purposive sampling, yaitu teknik penentuan sampel karena peneliti memiliki pertimbangan tujuan tertentu sesuai dengan tujuan penelitian (Sudjana dan Ibrahim, 1989). Pertimbangan penentuan sampel adalah: (1) sikap keterbukaan terhadap inovasi pembelajaran dan kesediaan untuk berkolaborasi dari pihak guru dan kepala TK yang dipilih; dan (2) kondisi sekolah yang memadai dari segi sarana dan fasilitas untuk dilakukan pengembangan model. Subyek penelitian pada tahap uji coba lapangan adalah guru kolaborator sebagai pelaksana pembelajaran terdiri atas dua orang guru TK dan siswa pada TK tersebut. Uji validasi produk pengembangan dilakukan dengan teknik penilaian terhadap draf produk pengembangan oleh dua orang ahli dengan menggunakan format skala penilaian.

Metode pengumpulan data yang digunakan adalah observasi lapangan, wawancara, tinjauan dokumen, telaah pakar (Expert Review) (cf. Richey \& Klein, 2007) dan kuesioner. Pada tahap studi pendahuluan, selama 2 (dua bulan) dilakukan pengumpulan data menggunnakan metode observasi, wawancara, tinjauan dokumen dan kuesioner. Pada tahap pengembangan model, penyusunan draf dan validasi data dilakukan selama 6 (enam) bulan. Instrumen pendukung untuk pengumpulan data penelitian meliputi: pedoman observasi, catatan lapangan, rekaman audio, dan foto dokumentasi, dokumen, dan skala penilaian. Data penelitian meliputi data kuantitatif dan data kualitatif. Data kuantitatif dihasilkan dari kuesioner tentang kondisi dan kebutuhan guru pada studi awal. Data kualitatif dihasilkan dari wawancara, observasi, dan studi dokummen pada studi awal dan data proses pengembangan. Teknik analisis kuantitatif digunakan untuk mengolah data studi pendahuluan. Hasil kuesioner dianalisis persentase dan dijelaskan secara kualitatif. Data uji lapangan berupa hasil implementasi model di lapangan dianalisis dengan teknik analisis kualitatif model mengalir (Milles \& Huberman, 1992). Aktivitas analisis meliputi: reduksi data, penyajian data, penyimpulan dan verifikasi.

\section{HASIL PENELITIAN}

Hasil studi awal terhadap kondisi dan kebutuhan guru menunjukkan bahwa semua guru menyusun perencanaan berupa Rencana Kegiatan Mingguan (RKM) dan Rencana Kegiatan Harian (RKH) sebelum pelaksanaan. Dalam menyusun perencanaan, sebagian besar guru (67\%) tidak mengalami kesulitan yang berarti, hanya sebagian kecil guru (33\%) mengalami kesulitan. Kesulitan guru adalah dalam penjabaran tema/subtema ke dalam indikator ketercapaian kompetensi dan nilainilai karakter, yang dinyatakan oleh sebagian guru (58\%). Kesulitan dalam penjabaran tema/subtema ke dalam scenario kegiatan juga dinyatakan oleh sebagian guru (50\%), sedangkan kesulitan dalam pemilihan dan penyiapan media yang sesuai dengan tema dialami oleh sebagian guru (42\%).

Dalam menyusun materi, guru (67\%) mengembangkan materi sendiri, sedangkan sebagian guru (23\%) tidak mengembangkan materi sendiri. Oleh karena itu, guru menggunakan materi yang diambil dari buku (83\%), dan mengembangkan materi bersama Tim guru (75\%). Sementara, penggunaan pengalaman bahasa sebagai materi juga dilakukan sebagian guru (58\%). Dalam hal integrasi pendidikan karakter dalam proses pengembangan pra-membaca menulis, sebagian besar guru (67\%) tidak menggunakan pendidikan karakter sebagai materi pengembangan. Hal ini 
didukung data bahwa 75\% guru mengalami kesulitan dalam memilih dan menjabarkan materi pengembangan pra-membaca menulis berbasis karakter.

Terkait dengan ketersediaan panduan guru, 50\% guru berpendapat bahwa panduan guru tidak mudah didapat. Menurut guru (67\%), tidak tersedianya panduan guru menyebabkan mereka tidak bisa memanfaatkan panduan secara maksimal.

Dalam hal perencanaan asesmen, 33\% guru selalu membuat perencanaan sebelum melaksanakan kegiatan. sedangkan $67 \%$ guru hanya kadang-kadang dan jarang menyusun perencanaan asesmen. Hal ini didukung fakta bahwa 50\% guru mengalami kesulitan dalam menjabarkan komponen keterampilan pra-membacaa menulis yang akan dinilai dan dalam menentukan cara melakukan penilaian pra-membaca menulis. Selain itu, fakta menunjukkan bahwa $67 \%$ guru mengalami kesulitan dalam melakukan asesmen pra-membaca menulis. Untuk mengatasi masalah tersebut. 75\% guru menyatakan bahwa mereka membutuhkan perangkat asesmen pramembaca menulis berbasis pendidikan karakter.

Berdasarkan hasil studi pendahuluan dan hasil kajian teoretis serta hasil diskusi dengan guru maka dikembangkanlah model pengembangan pra-membaca-menulis di TK yang diintegrasikan dengan pendidikan karakter. Model pengembangan digambarkan dalam bagan berikut.

Mode Pengembangan Kemampuan Pra-Membaca-Menulis Berbasis Karakter (MPKBPK)

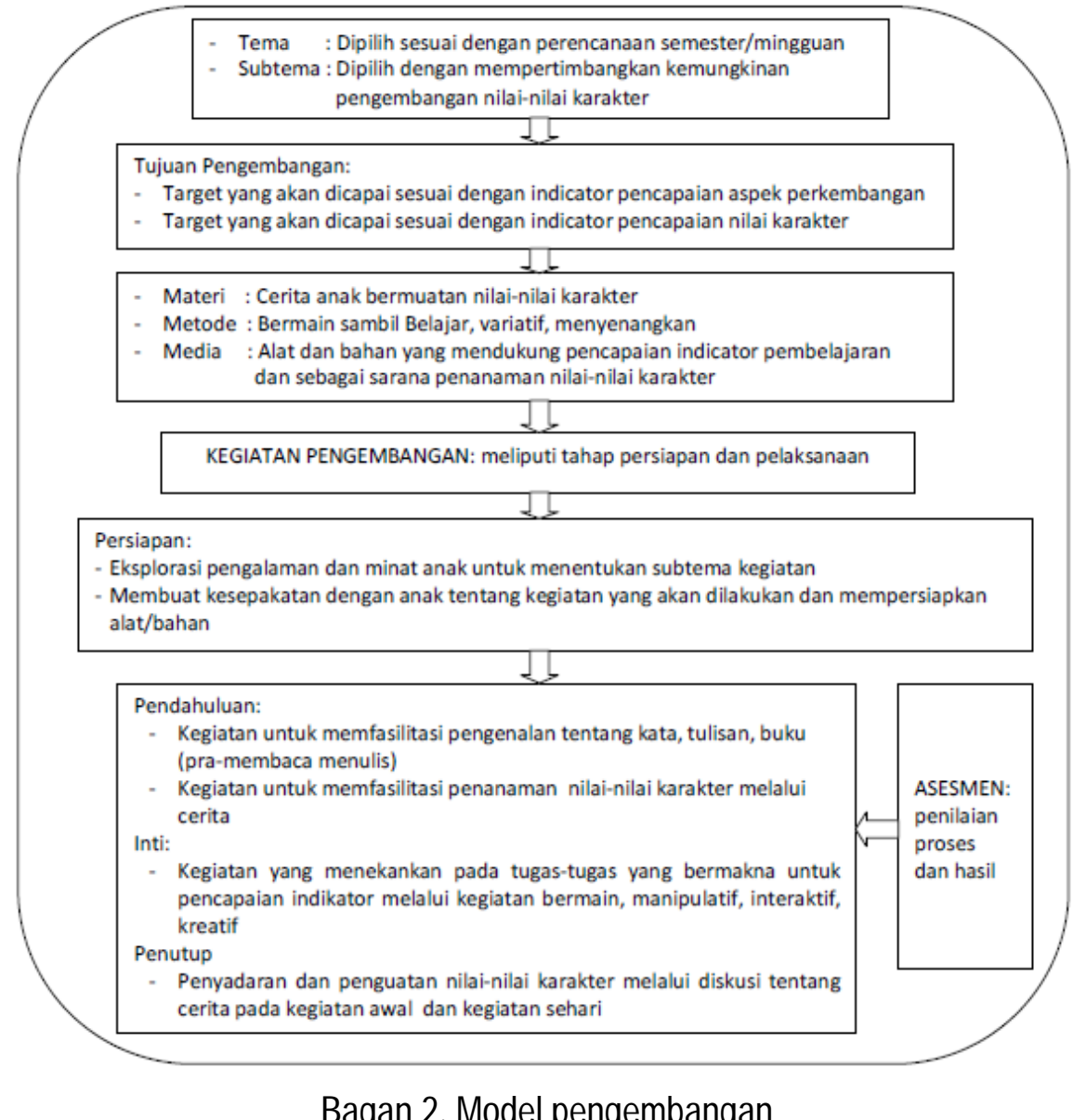

Bagan 2. Model pengembangan 


\section{HASIL VALIDASI}

Data pengembangan produk berupa draf produk, meliputi komponen: Panduan Guru, Silabus, RKM, RKH, Model Skenario Kegiatan Pengembangan, dan Materi Pengembangan. Draf produk pengembangan tersebut divalidasi (uji ahli) oleh dua orang pakar pembelajaran TK dan tiga orang guru TK. Hasil uji ahli berupa penilaian dikelompokkan dalam empat kategori, yakni: sangat baik (3,5-4); baik $(2,6-3,4)$; kurang baik $(1,6-2,5)$; sangat kurang baik $(0-1,5)$. Hasil uji validasi terhadap draf awal menunjukkan beberapa kekurangan yang harus diperbaiki. Saran dan masukan yang diberikan, baik oleh ahli maupun oleh guru menjadi bahan revisi draf. Oleh karena itu, draf model pengembangan mengalami beberapa perubahan dari draf awalnya. Perubahan adalah pada: (1) komponen panduan, penyederhanaan langkah-langkah dan konsistensi penggunaan istilah; (2) rencana kegiatan, pengurangan indikator sehingga penilaian/asesmen dapat lebih terfokus dan tidak terlalu banyak; (3) skenario pengembangan, langkah-langkah pengembangan dibuat lebih sederhana dan lebih runtut.

Hasil uji validasi terhadap produk pengembangan menunjukkan bahwa semua komponen telah memenuhi kriteria 'baik'. Hasil validasi (V-I \& V-2) terhadap produk pengembangan disajikan pada tabel berikut.

Tabel 1. Hasil Validasi Model Pengembangan

\begin{tabular}{lccccc}
\hline \multirow{2}{*}{ Komponen } & \multicolumn{2}{c}{ Skor Rata-rata } & & Rata-rata per & \multirow{2}{*}{ komponen } \\
\cline { 2 - 3 } & V-I & V-II & & Kualitas \\
\hline Materi & 3,70 & 3,00 & & 3,35 & Baik \\
\hline Panduan Guru & 3,75 & 3,15 & 3,45 & Baik \\
\hline Skenario Pengembangan & 3,60 & 3,18 & 3,38 & Baik \\
\hline Asesmen & 2,70 & 2,90 & 2,80 & Baik \\
\hline
\end{tabular}

Produk pengembangan berupa skenario kegiatan pengembangan diimplementasikan di kelas dengan diamati oleh pakar dan guru. Observasi dilakukan dengan menggunakan format validasi implementasi model. Hasil validasi model disajikan pada Tabel 2, sebagai berikut.

Tabel 2. Hasil Validasi Implementasi Model Pengembangan

\begin{tabular}{|c|c|c|c|c|}
\hline \multirow{2}{*}{ Indikator } & \multicolumn{2}{|c|}{ Nilai } & \multirow{2}{*}{$\begin{array}{l}\text { Rata- } \\
\text { rata }\end{array}$} & \multirow{2}{*}{$\begin{array}{c}\text { Rt. } \\
\text { Tahap }\end{array}$} \\
\hline & V-I & V-II & & \\
\hline \multicolumn{5}{|l|}{ Tahap persiapan } \\
\hline - $\quad$ Menyiapkan media/alat \& bahan & 3 & 4 & 3,5 & \multirow[b]{2}{*}{3} \\
\hline $\begin{array}{ll}- & \text { Mengecek kesiapan anak mengikuti kegiatan }\end{array}$ & 3 & 2 & 2,5 & \\
\hline \multicolumn{5}{|l|}{ Tahap Pelaksanaan } \\
\hline \multicolumn{5}{|l|}{ Pendahuluan } \\
\hline - $\quad$ Mengelola kegiatan pendahuluan & 4 & 4 & 4 & \multirow{2}{*}{4} \\
\hline - $\quad$ Pengembangan nilai karakter & 4 & 4 & 4 & \\
\hline \multicolumn{5}{|l|}{ Inti } \\
\hline $\begin{array}{ll} & \text { Pengembangan kemampuan pra-membaca menulis }\end{array}$ & 3 & 4 & 3,5 & \multirow{2}{*}{3} \\
\hline - $\quad$ Pengembangan nilai karakter & 3 & 2 & 2,5 & \\
\hline \multicolumn{5}{|l|}{ Penutup } \\
\hline - $\quad$ Penyadaran dan penguatan nilai karakter & 4 & 4 & 4 & 4 \\
\hline
\end{tabular}


Hasil validasi terhadap implementasi skenario pengembangan dalam kegiatan nyata menunjukkan bahwa pada semua tahap kegiatan, yakni tahap persiapan dan tahap pelaksanaan, yang meliputi kegiatan pendahuluan, inti, dan penutup, menunjukkan kualitas 'baik' (3) dan kualitas 'sangat baik' (4).

\section{PEMBAHASAN}

Pengembangan model secara konseptual didasarkan pada pandangan bahwa mengajarkan karakter harus dimulai sejak dini. Anak ibaratnya 'bahan bangunan' yang akan membentuk 'seorang dewasa yang bertanggung jawab' (Lickona, 1994). Oleh karena itu, karakter yang berkualitas harus dibentuk sejak anak usia dini. Usia dini merupakan masa kritis bagi pembentukan karakter seseorang. Pembentukan karakter yang telah dimulai di dalam lingkungan keluarga harus diteruskan di lembaga pendidikan PAUD/TK. Penanaman nilai-nilai karakter di TK selaras dengan fungsi utama pendidikan yang diamanatkan dalam UU Sisdiknas, "mengembangkan kemampuan dan membentuk watak serta peradaban bangsa yang bermartabat dalam rangka mencerdaskan kehidupan bangsa". Sesuai dengan amanat tersebut, pendidikan karakter di sekolah sejak TK sudah mempunyai landasan yang kokoh dalam rangka mengembangkan seluruh potensi peserta didik.

Model Pengembangan Kemampuan Pra-membaca-menulis Berbasis Karakter (MPKPBK) dikembangkan berdasarkan prinsip pembelajaran TK, yakni holistik, kontekstual, bermakna, dan menyenangkan. Prinsip holistik mengacu kepada tahap perkembangan anak, yang menurut Piaget berada pada masa praoperasional konkret. Pada masa ini, anak melihat dunia sebagai sesuatu yang utuh. Pembelajaran untuk anak usia ini dilakukan dengan pendekatan kontekstual, utuh, konkret, dan bermakna melalui penyediaan serangkaian pengalaman. Kegiatan pengembangan tidak dilakukan secara artifisial dalam beberapa kegiatan pengembangan secara terpisah-pisah.

Pengembangan model MPKPBK sesuai dengan prinsip-prinsip pembelajaran di TK yang menerapkan pendekatan tematik. Hal ini bukan merupakan hal yang baru bagi guru TK. Namun, pengembangan model MPKPBK berbeda dengan model pengembangan yang lain karena pada setiap langkah pengembangan memberikan penekanan dan didasarkan pada upaya penanaman nilai karakter peserta didik. Perbedaan tersebut diawali dari penyusunan rencana pengembangan yang berbasis pendidikan karakter dan dilanjutkan dengan pelaksanaan pengembangan yang juga menambahkan langkah-langkah kegiatan yang menekankan pada penanaman nilai-nilai karakter.

Penyusunan rencana kegiatan dimulai dari pemilihan tema/subtema, kemudian menetapkan tujuan pengembangan. Dalam menyusun rencana pengembangan model MPKPBK, rumusan tujuan pengembangan dimodifikasi dan disesuaikan dengan capaian perkembangan sehingga tujuan pengembangan selain mencakup indikator pencapaian aspek perkembangan juga mencantumkan indikator pencapaian nilai-nilai karakter. Dengan demikian, rumusan indikator memuat dua aspek sekaligus, yaitu aspek kemampuan dan aspek karakter, contoh: "dapat mewarnai gambar huruf dengan rapi dan bersih", "dapat bercerita tentang gambar yang dibuat dengan percaya diri".

Pemilihan kegiatan dikembangkan dengan bertolak dari tema. Tema dapat dipilih dan diambil dari perencanaan semester yang telah dikembangkan oleh guru secara bersama (tim). Dari tema tersebut dikembangkan menjadi sub-subtema atau topik. Pemilihan subtema dilakukan dengan mempertimbangkan minat dan kebutuhan peserta didik. Pemilihan kegiatan dilakukan melalui dialog dan eksplorasi pengalaman anak terkait dengan subtema yang dipilih sehingga materi dan kegiatan pengembangan merupakan dunia yang tidak asing bagi anak.

Pada aspek kegiatan pengembangan, dilakukan penambahan dan modifikasi langkahlangkah pengembangan, yaitu dengan menambahkan langkah pengembangan yang bermuatan 
karakter. Langkah kegiatan dimulai dari kegiatan pendahuluan, kegiatan inti, sampai pada kegiatan penutup diberi penekanan agar peserta didik mempraktikkan nilai-nilai karakter yang ditargetkan.

\section{Kegiatan Pendahuluan}

Pada kegiatan pendahuluan, langkah standar yang harus ada adalah: pembukaan, orientasi, apersepsi, dan motivasi. Dalam model MPKPBK, langkah-langkah tersebut dilakukan dengan menambahkan kegiatan untuk mengenalkan, membangun, dan/atau menguatkan nilai-nilai karakter, serta membantu terjadinya internalisasi nilai-nilai. Contoh kegiatan berbasis karakter pada kegiatan pendahuluan adalah sebagai berikut:

- $\quad$ Guru mengucapkan salam dengan ramah (nilai yang ditanamkan: santun, peduli)

- $\quad$ Mengecek kehadiran peserta didik (nilai yang ditanamkan: disiplin)

- $\quad$ Mendoakan peserta didik yang tidak hadir karena sakit (nilai yang ditanamkan: peduli, religius)

- $\quad$ Memberikan pujian ketika setiap anak hadir tepat waktu (nilai yang ditanamkan: peduli, menghargai, disiplin).

- Menanyai anak yang terlambat hadir dengan sopan (nilai yang ditanamkan: disiplin, santun, peduli)

\section{Kegiatan Inti}

Pada kegiatan inti, peserta didik difasilitasi melalui kegiatan belajar yang menyenangkan yakni sambil bermain. Pada tahap ini, dilakukan kegiatan untuk mengembangkan kemampuan dan keterampilan serta sikap melalui kegiatan yang berpusat pada peserta didik. Dengan penerapan prinsip kontekstual dalam kegiatan pengembangan diharapkan dapat memfasilitasi terjadinya internalisasi nilai-nilai karakter. Contoh kegiatan pengembangan berbasis pendidikan karakter pada kegiatan inti, sebagai berikut.

- $\quad$ Mengaitkan cerita pada kegiatan awal, yakni sikap kerja sama Miko dan Nino dalam cerita, peserta didik disadarkan akan pentingnya bekerja sama dalam menyelesaikan tugas-tugas dalam kelompok, seperti, memasangkan gambar dan tulisan, mewarnai (contoh nilai yang ditanamkan: kerja sama, menghargai)

- $\quad$ Memfasilitasi terjadinya dialog dan interaksi dalam kelompok, guru memberi penekanan agar peserta didik saling membantu dan bekerja sama agar hasil kerja mereka baik (nilai yang ditanamkan: kerja sama, saling menghargai, peduli).

- $\quad$ Peserta didik diberi berbagai pilihan kegiatan yang bervariasi dengan berbagai media/bahan, yang memungkinkan mereka secara bebas memilih kegiatan yang diminati, seperti, mewarnai huruf, memasangkan gambar dan tulisan, merangkai huruf menjadi kata, menuliskan nama sendiri pada hasil karya (contoh nilai yang ditanamkan: kreatif, demokratis, menghargai prestasi, percaya diri).

- $\quad$ Melibatkan peserta didik secara aktif melakukan setiap kegiatan (contoh nilai yang ditanamkan: percaya diri, mandiri, gigih).

- Memfasilitasi peserta didik untuk berkompetisi secara sehat untuk mengahsilkan karya terbaik, dengan memajang hasil karya (contoh nilai yang ditanamkan: kerja keras, gigih, menghargai)

- $\quad$ Memberikan umpan balik yang positif dan penguatan terhadap keberhasilan peserta didik (contoh nilai yang ditanamkan: percaya diri, mengargai, santun, logis). 


\section{Kegiatan Penutup}

Kegiatan penutup dimaksudkan untuk menyatukan kembali seluruh perolehan hasil kegiatan sehari, baik muatan perkembangan maupun muatan karakter. Kegiatan penutup dilakukan diskusi dan dialog untuk mengaitkan kembali seluruh kegiatan sehari dengan isi cerita pada kegiatan pendahuluan. Guru dapat melakukan penguatan terhadap sikap dan perilaku positif serta hasil karya peserta didik. Kegaitan penutup untuk menanamkan karakter adalah sebagai berikut.

- $\quad$ Melakukan tanya jawab tentang kegiatan sehari yang telah dilakukan. Guru mengaitkan karakter tokoh cerita yang baik dengan sikap dan perilaku peserta didik dalam melakukan kegiatan (contoh nilai yang ditanamkan: kritis, logis, jujur).

- $\quad$ Melakukan refleksi terhadap kegiatan yang telah dilakukan, menanyakan apakah peserta didik telah menyelesaikan tugas-tugas yang diberikan dengan baik (contoh nilai yang ditanamkan: jujur, menyadari kelebihan dan kekurangan).

- $\quad$ Memberikan umpan balik terhadap proses dan hasil kegiatan, dengan memberikan pujian atau penghargaan (nilai yang ditanamkan: menghargai prestasi, percaya diri, santun).

- Membiasakan berdoa untuk mengakhiri kegiatan (nilai yang ditanamkan: sikap selalu bersyukur, religius).

\section{SIMPULAN}

Simpulan hasil penelitian adalah sebagai berikut. Pertama, dalam pelaksanaan kegiatan pengembangan kemampuan pra-membaca-menulis berbasis karakter di TK, kebutuhan guru terdiri atas: pengembangan materi, panduan untuk guru, penyusunan RKH dan skenario kegiatan. Kesulitan guru adalah dalam penjabaran tema/subtema ke dalam indikator pencapaian kompetensi dan nilai karakter, penjabaran tema/subtema ke dalam skenario kegiatan, pemilihan dan penyiapan media yang akan digunakan.

Kedua, Model Pengembangan Kemampuan Pra-membaca-menulis Berbasis Karakter dikembangkan dengan memperhatikan prinsip-prinsip pengembangan di TK, yakni holistik, kontekstual, bermakna, dan menyenangkan. Prinsip-prinsip tersebut melandasi keseluruhan model, yakni: (1) panduan untuk guru, RKM, RKH, skenario kegiatan, dan materi pengembangan; (2) komponen desain model meliputi: tema/subtema; tujuan pengembangan membaca menulis dan pendidikan karakter; materi cerita bermuatan karakter; metode bermain sambil belajar; media/bahan/alat permainan, gambar, kartu huruf/kata; kegiatan pengembangan meliputi persiapan, pendahuluan, inti, penutup ; dan asesmen.

Ketiga, Model Pengembangan Kemampuan Pra-membaca-menulis Berbasis Karakter terbukti dapat mengembangkan nilai-nilai karakter anak dalam setiap tahap kegiatan, meliputi: (1) kegiatan pendahuluan,: santun, religius, disiplin, menghargai, peduli; (2) kegiatan inti: kerja sama, menghargai orang lain, peduli, kreatif, demokratis, menghargai prestasi, percaya diri, mandiri, gigih, santun, logis; (3) kegiatan penutup: kritis, logis, jujur, menyadari kelebihan dan kekurangan, menghargai prestasi, percaya diri, santun.

Implikasi dari simpulan hasil penelitian adalah: (1) memasukkan aspek pendidikan karakter dalam penyusunan rencana pengembangan, khususnya pada rumusan tujuan pengembangan, materi pengembangan, dan kegiatan pengembangan; (2) memanfaatkan cerita anak sebagai titik tolak pengembangan materi kegiatan; (3) kepala TK dan guru perlu orientasi tentang MPKPBK agar memiliki pemahaman dan semangat untuk melaksanakan kegiatan pengembangan pra-membacamenulis berbasis pendidikan karakter; (4) sosialisasi dan komunikasi dengan orang tua anak 
sehingga dapat memberikan dukungan positif, khususnya dalam mendukung pendidikan karakter yang selaras dengan pengembangan yang dilakukan di TK.

\section{REFERENSI}

Borg, W. R. \& Gall, M. D. (1983). Educational research, an introdution. London: Longman, Inc. Elmubarok, Z. (2009). Membumikan pendidikan nilai, mengumpulkan yang terserak, menyambung yang terputus dan menyatukan yang tercerai. Bandung: Alfabeta.

Frose, V. (1991). Whole language-practice and theory. Boston: Allyn and Bacon. Hasan, M. (2010). PAUD (Pendidikan Anak Usia Dini). Jogjakarta: Diva Press.

http://www.garuda.dikti.go.id/jurnal/detil/id/48:2818/q/Pembelajaran Membaca Anak Usia Dini/offset/0/limit.

Hurlok, E. B. (1992). Alih bahasa Tjandrasa, M. Perkembangan anak. Jakarta: Penerbit Erlangga.

Kementerian Pendidikan Nasional. (2010). Kurikulum taman kanak-kanak, pedoman pengembangan program pembelajaran di taman kanak-kanak. Jakarta: Dirjen Manajememn Pendidikan Dasar dan Menengah Direktorat Pembinaan TK dan SD.

Kementerian Pendidikan Nasional. (2010). Tingkat pencapaian perkembangan anak taman kanakkanak. Jakarta: Dirjen Manajemen Pendidikan Dasar dan Menengah Direktorat Pembinaan TK dan SD.

Lickona, T. (1994). Raising good children: From birth through the teenage years. New York: Bantam Books.

Megawangi, R. (2009). Pendidikan karakter, solusi yang tepat untuk membangun bangsa. Jakarta: Indonesia Heritage Foundation.

Pusat Kurikulum. (2010). Pengembangan pendidikan dan karakter bangsa. Jakarta: Kemdiknas, Badan Penelitian dan Pengembangan, Puskur.

Republik Indonesia. (2010). Kebijakan nasional pembangunan karakter bangsa. Jakarta: Kemko Kesejahteraan Rakyat.

Richey, R. C., Klein. J.D. (2007). Design and development research, methods, strategies, and issues. London: Lawrence Erlbaum Associates, Publishers.

Seefeldt, C., Wasik, B. A. (2008). Penerjemah Pius Nasar. Pendidikan anak usia dini, menyiapkan anak usia tiga, empat, dan lima tahun masuk sekolah. Jakarta: PT Indeks.

Sudjana, N. \& Ibrahim. (1989). Penelitian dan penilaian pendidikan. Bandung: Sinar Baru.

Sugiyono. (2009). Metode penelitian kuantitatif kualitatif dan $R \& D$. Bandung: Penerbit Alfabeta.

Wahyuni, S. \& Ibrahim, A. S. (2012). Perencanaan pembelajaran bahasa berkarakter. Bandung: PT Refika Aditama. 